\title{
透析回路内に形成された淡黄色顆粒物の検討
}

\author{
青木 弘 之 ${ }^{1}$ 藤 岡 紀 昭 ${ }^{1}$ 阿部 正 典 ${ }^{1}$ 松岡 由美子 ${ }^{1}$ \\ 大森容子 ${ }^{1}$ 葉山修陽 ${ }^{2}$ 佐藤茂 ${ }^{3}$ 大薗 英 -4 \\ 恵章会御徒町腎クリニック さ导いたまつきの森クリニック² \\ 日本医科大学形態解析共同研究施設 ${ }^{3}$ 日本医科大学微生物免疫 4
}

\begin{abstract}
キーワード：維持血液透析，血小板血栓，低温刺激，ヘパリン，回路内加温
〈要旨〉

血液透析施行時, 透析開始直後から血液回路内に淡黄色顆粒物が付着し回路内凝固などのトラブルの原因となる ことがある. 冬季に多く, プライミング時に血液回路を $37^{\circ} \mathrm{C}$ ま゙加温すると回避される場合がある. 今回この顆粒 物の本態を検討し成因を推定した. 電子顕微鏡所見から, 顆粒物は活性化血小板による血小板血栓であった. 5 名 の症例に性差, 透析歴や原疾患の共通性はなく, 回路内凝固以外共通症状もなかった. 低温刺激に関与するクリオ グロブリン血症や寒冷凝集素症も認められず, ヘパリン起因性血小板減少症関連の抗体もすべて陰性であった. 顆 粒物が形成されない透析患者と比較して血液検査上の差はなく血小板数も正常範囲にあったが, ヘパリン化による 平均血小板容積 $(M P V)$ の低下率が大きかった $(p=0.016)$. 未分画ヘパリンの増量は顆粒物形成に影響しなかっ たが, プライミング時の回路内加温および低分子ヘパリンやナファモスタットへの抗凝固薬の変更で抑制され回路 内凝固の回避に成功した. この病態は低体温下手術時の全身ヘパリン化で認められる血小板減少症に類似し, 淡黄 色顆粒物の成因として回路内の低温刺激と高分子分画のヘパリンが複合的に関与していると考えられた.
\end{abstract}

\section{Pale yellow granules forming in hemodialysis circuit}

Hiroyuki Aoki', Noriaki Fujioka', Masanori Abe', Yumiko Matsuoka', Yoko Omori', Naoaki Hayama', Shigeru Sato ${ }^{3}$ and Eiichi Osono ${ }^{4}$

Okachimachi Kidney Clinic ${ }^{1}$; Saitama Tsuki no mori Clinic ${ }^{2}$; Joint Research Facility for Morphological Analysis, Nippon Medical School ${ }^{3}$; Department of Microbiology and Immunology, Nippon Medical School ${ }^{4}$

Key words : maintenance hemodialysis, platelet thrombus, cold stimulus, heparin, heating in the circuit

$\langle$ Abstract〉

Pale yellow granules start to adhere in the dialysis circuit immediately after hemodialysis initiation, and coagulate the circuit in some cases. This frequently occurs in winter, and is avoided by warming the dialysis circuit to $37^{\circ} \mathrm{C}$ at the time of priming. We investigated the granules and cause of their formation. On electron microscopy, the granules were platelet thrombi formed by activated platelets. There were no common findings in the past medical history of dialysis or primary disease and no common symptom other than coagulation of the circuit among 5 cases. No cryoglobulinemia nor cold agglutinin disease related to cold stimulation was noted, and all antibodies related to heparin-induced thrombocytopenia were negative. Compared to non-granule-forming dialysis patients, no difference was noted on blood testing, and the platelet count was within the normal range, but the rate of heparin-induced reduction of the mean platelet volume (MPV) was greater $(p=0.016)$. An increase in the non-fractionated heparin dose did not influence granule formation, but warming of the dialysis circuit at the time of priming and switch of the anticoagulant to low-molecular-weight heparin or nafamostat inhibited granule formation and avoided coagulation of the circuit. This pathology is similar to thrombocytopenia in patients under systemic heparinization in hypothermic surgery, suggesting that cold stimulation in the dialysis circuit and the macromolecular heparin fraction are involved in pale yellow granule formation.

青木 弘之 恵章会御徒町腎クリニック † 110-0005 東京都台東区上野 5-8-5 CP10 ビル $2 \mathrm{~F}$

Hiroyuki Aoki Tel : 03-5812-2861 Fax : 03-5812-2863

〔受付日：2011 年 6 月 30 日, 受理日 : 2011 年 10 月 21 日〕 


\section{緒言}

血液透析施行時に発生するトラブルのひとつに回路 内凝固がある。一般に抗凝固薬量の不足や脱血不良に よる血液凝集が原因で生じるが ${ }^{1)}$ ，透析開始時より淡 黄色の顆粒物 (図 1) が形成され血液回路やエアトラッ プチャンバ内に付着して静脈圧上昇や回路内凝固をひ き起こすことがある.このパターンの回路内凝固を起 こす病態としてクリオグロブリン血症が知られてお り，血液回路を $37^{\circ} \mathrm{C}$ 以上に加温（図 $2 \mathrm{a}$ ) すると $\gamma$ グロ

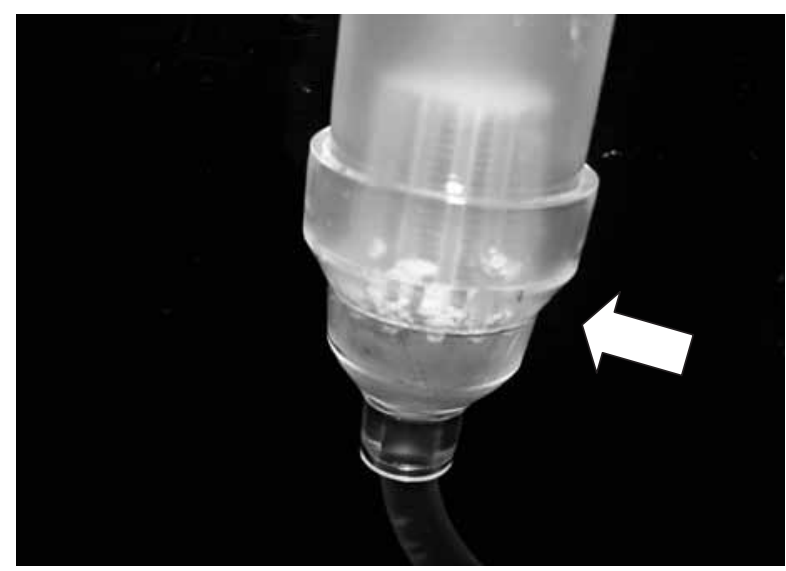

図 1 形成された顆粒物の形状

動脈チャンバ内のコーン型メッシュにトラップされた淡黄 色〜白色の顆粒物.
ブリン（IgG または IgM）の凝集，さらには回路内凝 固自体を回避できたとの報告 ${ }^{2}$ がある。そこで当院で も血液回路の加温を試みたところ，同様に顆粒物形成 が抑制されトラブルが回避された。 しかしわれわれの 症例ではクリオグロブリンが陰性であった.

\section{I . 目的}

血液回路内の淡黄色顆粒物の本態を解析しその成因 を推定する。

\section{II . 症例と方法}

\section{1. 症例の背景と臨床像}

当院で維持透析をうけている患者 85 名 (男性 66 名, 女性 19 名）中, 動・静脈エアトラップチャンバ内に淡 黄色の顆粒物形成を視認した患者 5 名（男性 4 名, 女 性 1 名）に回路凝固への対応を含め文章にて研究協力 に同意を得た． 5 例とも週 3 回の血液透析を受けてお り, 統計学的解析は平均值土標準偏差で表した.

診療録と透析チャートから各症例の症候および顆粒 物の形成状況を検討した. 血液検查は 2 日空きの透析 前に行った. 定期的に施行している血球計算検査・生 化学検査以外に, 顆粒物形成に関与する病態としてク リオグロブリン血症 ${ }^{2,3)}$ と寒冷凝集素症 ${ }^{4,5)}$, ヘパリン起 因性血小板減少症（Heparin-induced thrombocytope-

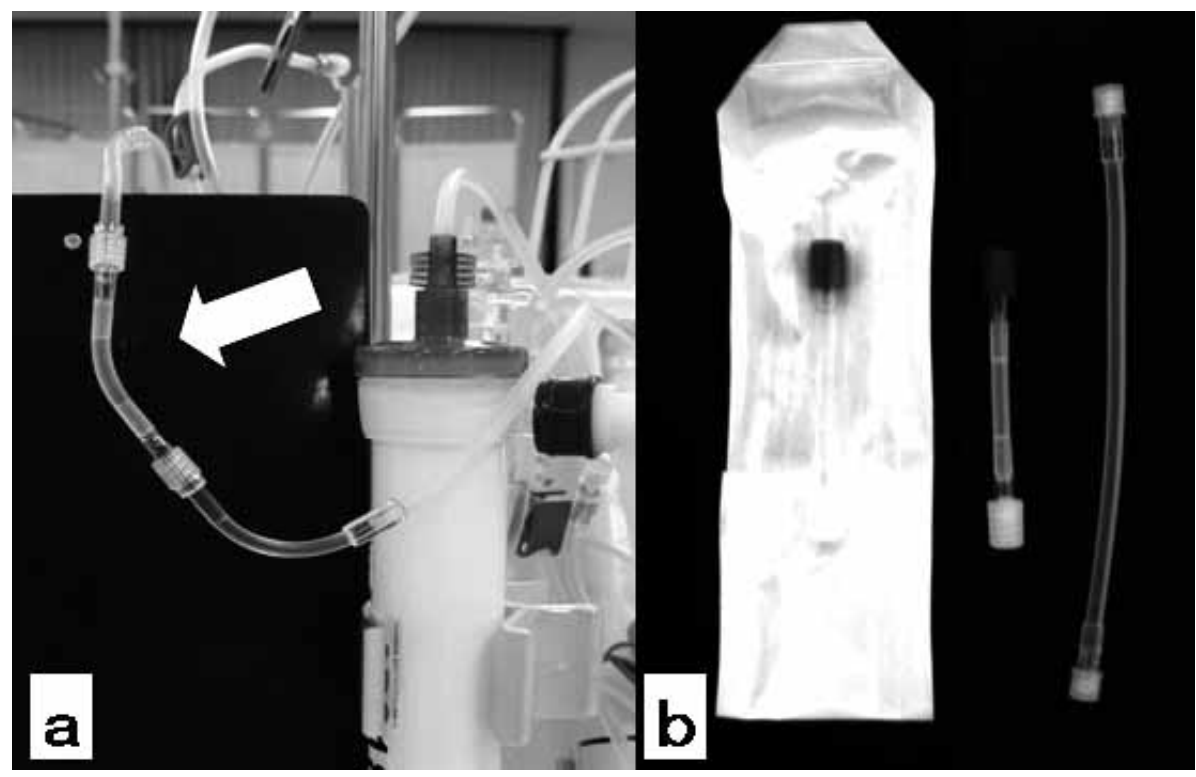

図 2 回路内加温

血液回路の脱血・返血用穿刺針接続部の間に，バイパス用回路（図 $2 b ）$ を装着しループを 形成する． $37.5^{\circ} \mathrm{C}$ の透析液をダイアライザーに流し，ポンプを $80 \mathrm{~mL} / \mathrm{min} に$ 設定して回 路内の生理食塩水を循環させ，透析開始時まで回路を加温する，バイパス用回路の着脱時 に清潔操作を要するが, 手技は簡便で熟練に時間を要さない. 
表 1 患者背景と主要検査結果

\begin{tabular}{|c|c|c|c|c|c|c|c|c|c|}
\hline \multirow[b]{2}{*}{ 症例 } & \multirow[b]{2}{*}{ 性別 } & \multirow{2}{*}{$\begin{array}{l}\text { 年齢 } \\
\text { (歳) }\end{array}$} & \multirow{2}{*}{$\begin{array}{l}\text { 透析歴 } \\
\text { (年) }\end{array}$} & \multirow[b]{2}{*}{ 原疾患 } & \multirow[b]{2}{*}{ 感染症 } & \multirow{2}{*}{$\begin{array}{l}\text { 血小板数 } \\
\left(10^{4} / \mu \mathrm{L}\right)\end{array}$} & \multicolumn{3}{|c|}{ 抗体価検査 } \\
\hline & & & & & & & $\begin{array}{c}\text { クリオグロブリン } \\
\text { 定性 }\end{array}$ & 寒冷凝集素価 & $\begin{array}{c}\text { 抗 PF4・ヘパリン } \\
\text { 複合体抗体 }\end{array}$ \\
\hline A & $\mathrm{M}$ & 58 & 7.5 & $\mathrm{DM}$ & なし & 27.8 & 陰性 & 8 倍 & 陰性 \\
\hline B & $\mathrm{M}$ & 59 & 15.6 & 腎硬化症 & $\mathrm{HCV}$ & 19.8 & 陰性 & 8 倍 & 陰性 \\
\hline $\mathrm{C}$ & $\mathrm{M}$ & 62 & 4.25 & 尿路結核 & なし & 28.4 & 陰性 & 16 倍 & 陰性 \\
\hline $\mathrm{D}$ & M & 63 & 7 & $\mathrm{DM}$ & なし & 21.8 & 陰性 & 8 倍 & 陰性 \\
\hline $\mathrm{E}$ & $\mathrm{F}$ & 44 & 4.92 & CGN & なし & 22 & 陰性 & 16 倍 & 陰性 \\
\hline
\end{tabular}

表 2 顆粒物形成の対処とその成否

\begin{tabular}{|c|c|c|c|c|c|c|c|}
\hline \multirow[b]{2}{*}{ 症例 } & \multirow{2}{*}{$\begin{array}{c}\text { 顆粒物 } \\
\text { 形成度 } \\
\text { (HD 終了時) }\end{array}$} & \multirow{2}{*}{$\begin{array}{c}\text { 回路 } \\
\text { 凝固歴 } \\
\text { (HD 中) }\end{array}$} & \multicolumn{5}{|c|}{ 対処 } \\
\hline & & & $\begin{array}{c}\text { 回路内 } \\
\text { 加温. }\end{array}$ & $\begin{array}{l}\text { コーン型 } \\
\text { チャンバ }\end{array}$ & $\begin{array}{c}\text { ヘパリン } \\
\text { の増量 }\end{array}$ & $\begin{array}{l}\text { 低分子 } \\
\text { ペリン }\end{array}$ & $\begin{array}{c}\text { メシル酸 } \\
\text { ナファモスタット }\end{array}$ \\
\hline A & $(3+)$ & あり & $(3+) \rightarrow(2+)$ & 効果なし & 効果なし & $(3+) \rightarrow(+)$ & $(3+) \rightarrow(+)$ \\
\hline B & $(3+)$ & あり & $(3+) \rightarrow(2+)$ & 効果なし & 効果なし & $(3+) \rightarrow(+)$ & $(3+) \rightarrow(+)$ \\
\hline $\mathrm{C}$ & $(2+)$ & あり & $(2+) \rightarrow(+)$ & 効果なし & 効果なし & $(2+) \rightarrow(-)$ & $(2+) \rightarrow(+)$ \\
\hline $\mathrm{D}$ & $(+)$ & なし & $(+) \rightarrow(-)$ & $\mathrm{ND}$ & 効果なし & $(+) \rightarrow(-)$ & $\mathrm{ND}$ \\
\hline $\mathrm{E}$ & $(+)$ & なし & ND & ND & ND & $(+) \rightarrow(-)$ & ND \\
\hline
\end{tabular}

nia $:$ HIT $)^{6)}$ を疑いそれぞれの抗体価を測定した. ク リオグロブリン定性検査・寒冷凝集素価の血清は検査 まで常温で保存し，抗 PF4・ヘパリン複合体抗体は $3.2 \%$ クエン酸 $\mathrm{Na}$ 入り採血管で採血し血漿を冷蔵保 存した。

\section{2．顆粒物形成を抑制するための対処}

プライミング方法・血液回路・抗凝固薬の変更を行っ た.これらの対処により顆粒物形成がどう変化したか 観察した.

回路内加温（図 2) は, 透析開始時の血液回路自体の 温度を体温に近づける目的で行った. 予めプライミン グを済ませた血液回路の脱血・返血用穿刺針接続部の 間をバイパス用回路（図 2b）で繋ぎループ状にした。 $37.5^{\circ} \mathrm{C}$ に設定した透析液をダイアライザーに流して血 液回路内の生理食塩水を加温し, 透析開始時まで 80 $\mathrm{mL} / \mathrm{min}$ 程度で循環させた。また血液回路による血球 成分への物理的刺激を軽減する目的で，一部の症例に エアトラップチャンバの異物除去メッシュがコーン型 （図1）のものを用いた.

透析中の過凝固状態への対応として，未分画へパリ ンを 10〜 20\%増量, 抗凝固薬を等用量の低分子へパリ ンやメシル酸ナファモスタット $(30 \mathrm{mg} /$ 時 $)$ へ変更した.

\section{3. 顆粒物の形態的検討}

血液回路内の淡黄色顆粒物を透析終了後直ちに採取 し，2.5\%グルタールアルデヒド固定および四酸化才 スミュウムで固定し，エポキシ樹脂にて包埋した。こ の試料を光学顕微鏡用には準超薄切片としてトルイジ ンブルー染色した。また，電子顕微鏡用には超薄切片
としてウランと鉛で電子染色し透過型電子顕微鏡にて 観察した.

\section{4. ヘパリン化による血小板数・血小板容積の検討} 症例の EDTA 化血とへパリン化血を血液透析前に 採取し, 血小板数・血小板凝集の有無・平均血小板容 積 (mean platelet volume : MPV) を検討した。さら に症例と性別・年齢・透析歴・原疾患が同等な透析患 者で顆粒物の形成が認められていない患者に協力を依 頼し，同意の得られた 5 例を対照として同様の検査を 行い比較した。検体は室温で保存し検査機関に移送 し，データは平均值土標準偏差で表した．症例と対照 との差は分散の等しくない 2 群間の $t$ 検定（ウエルチ の $t$ 検定）を Stat view 最終版を用いて求め, $\mathrm{p}<0.05$ を統計学的に有意とした

\section{III. 結 果}

\section{1．症例の背景と臨床像}

症例の背景を示す (表 1)。年齢は $57.2 \pm 4.5$ 歳, 透 析歴は $7.9 \pm 7.6$ 年, 原疾患は糖尿病性腎症 2 名, 腎硬 化症 1 名, 尿路結核 1 名, 慢性糸球体腎炎 1 名であっ た。透析条件としてダイアライザーは 3 名がポリスル フォン膜, 2 名が再生セルロース膜を用い, 抗凝固薬 は未分画へパリンを初回投与 800〜1,000 単位，一回 総投与量 $3,000 〜 5,000$ 単位を使用していた。症例は 当院全患者の $5.9 \%$ にあたり比率は男性 $6.1 \%$ ，女性 $5.3 \%$ と男女差はみられなかった. 全例維持期の患者 で，全身性の血小板血栓症や血小板減少症に伴う易出 
血性や粘膜出血, 紫斑, 深部静脈血栓症等の症状を示 すものはなかった。症例に高度の貧血や多血症はみら れず，白血球数やその分画も正常であった．血小板数 にも $19.8 \sim 28.4 \times 10^{4} / \mu \mathrm{L}$ と異常はなく進行性の減少 を示すものもなかった. また, 肝機能・脂質代謝異常 もみられなかった. 1 名 (case B) クリオグロブリン 血症に関与するとされる HCV 抗体の陽性者がいた. しかしクリオグロブリン定性検査はすべて陰性であ り, 代表的症状の紫斑, レイノー現象, 関節痛もみら れなかった．寒冷凝集素価は陽性所見 256 倍以上に対 し 5 名とも 8〜16 倍と陰性であった．また，HIT（II 型）で形成される抗 PF4・ヘパリン複合体抗体も陰性 であった。

\section{2. 顆粒物形成を抑制するための対処と経過}

プライミング方法・血液回路・抗凝固薬の変更に伴 う顆粒物の形成状態の変化を表 2 に示す。全例で透析 終了時の生理食塩水による血液回収後にチャンバ内に 顆粒物が確認された．顆粒物は主に動・静脈チャンバ のメッシュ部に多く視認されるが, メッシュ部以外で も血液回路内全体にみられ肉眼的に白色から淡黄色, 大きさは芥子粒〜米粒大で不整型であった（図 1)。透 析開始直後から観察されることがあるもの（2 名 case A，B）や，開始後 1〜2 時間で静脈圧上昇をきたすも の (4 名 case A, B, C, D), 透析終了間際に顆粒物に よりエアトラップチャンバが完全に凝固したことがあ るもの（3名 case A, B, C）がいた.

顆粒物の形成量が多く回路凝固歴のある 3 名を含む 4 名に対して回路内加温（図 2) を行った。透析開始時 に血液回路自体を加温しておくと，4名とも顆粒物の 形成が抑えられ回路内凝固の頻度が低下した。一方, チャンバ内メッシュをコーン型に変更しても顆粒物形 成を抑制するには至らなかった。

Case Eを除く 4 名にへパリンの増量を試みると， ダイアライザーや血液回路内壁の赤血球による残血 (赤色血栓) は軽減されたが顆粒物は増量前と比べ変 化がなかった。 しかし，未分画へパリンと等用量の低 分子ヘパリンを用いて透析を施行すると， 5 名すべて で顆粒物形成が抑制された。また，顆粒物形成の多い 3 名にメシル酸ナファモスタット $(30 \mathrm{mg} /$ 時, 総量 100〜120 mg）を使用したところ 3 名とも顆粒物形成 が抑制された（表 4)。これらの症例に対し，現在冬期 は低分子へパリンと回路内加温で対処しているが，夏 期は顆粒物形成の落ち着いている症例もおり case B, $\mathrm{D}$ は回路内加温のみ case E は通常の条件で透析を 行っている.

\section{3. 顆粒物の形態的検討}

3 名（case A, B, C）の顆粒物を検討した. トルイ ジンブルー染色の光学顕微鏡下の観察では一部に好中 球や赤血球の混入を伴う無構造物（図 3a, case A）で あり, 透過型電子顕微鏡低倍率では顆粒物は径 3 4 $\mu \mathrm{m}$ の粒子の集合体で, 混入した好中球や赤血球と比 較し小型であった。高倍率でこの粒子は円盤形で核は なく二つの構造の違う小胞を含んでいる血小板であっ た。また, 中には細胞質突起を出しているものや小胞 を放出している血小板の活性化像が観察された（図 3b, case A). 顆粒物内には白血球が多く混入してい たが，好中球のみが選択的に取り込まれ単球やリンパ 球は認められなかった. Case B，Cにおいても同様の 結果が得られたが時間的に古い印象があり崩壊した血. 小板像が認められた. また 3 名とも血小板血栓周囲に は凝固系の活性化によるフィブリンの析出がみられた （図 3c, case B）が, 好中球には細胞質突起を出すなど の活性化像を認めなかった。

\section{4. 血小板関連検査}

ヘパリン化による血小板数・血小板凝集の有無・ MPV の変化を, 症例と他の透析患者（対照）とで比較 した（図 4). 両群ともEDTA 化血と比較してへパリ ン化血では血小板数の減少 (症例 : $23.5 \pm 2.8 \rightarrow 14.3 \pm$ $4.4 \times 10^{4} / \mu \mathrm{L}$, 対照 : $\left.22.0 \pm 3.8 \rightarrow 13.5 \pm 3.5 \times 10^{4} / \mu \mathrm{L}\right)$ と MPV の低下 (症例 : $12.1 \pm 1.2 \rightarrow 10.6 \pm 1.3 \mathrm{fl}$, 対 照 : $11.0 \pm 0.9 \rightarrow 10.5 \pm 0.8 \mathrm{fl} ）$ が認められ，血小板の 凝集像も認められた。 しかし症例では, MPVが基準 值 $(9.7 \sim 12.6 \mathrm{fl})$ から逸脱する割合が高く, さらにへ パリン化による MPVの低下率は症例で $-12.0 \pm$ $4.4 \%$ と対照群の $-4.5 \pm 1.3 \%$ より有意 $(\mathrm{p}=0.016)$ に大きかった.

\section{IV. 考察}

顆粒物が形成される成因について，透析開始時の回 路内加温により顆粒物形成が抑制されたことから血液 回路内の低温刺激が関与していること，また低分子へ パリンやメシル酸ナファモスタットへの変更で顆粒物 が減少したことにより未分画へパリンが大きく関与し ていることが推定された。輸注用の血小板製剤の検 討 ${ }^{7,8)}$ で, 冷蔵保存によって血小板数の減少と血小板の 細胞質突起形成などの活性化が顕著になることが知ら れている。しかしこれらは低温刺激単独で生じたもの であり, 症例の透析中の条件と完全には合致しない. またへパリン関連の過凝固状態であることから HIT を疑ったが，抗 PF4・ヘパリン複合体抗体は㓌性であ 


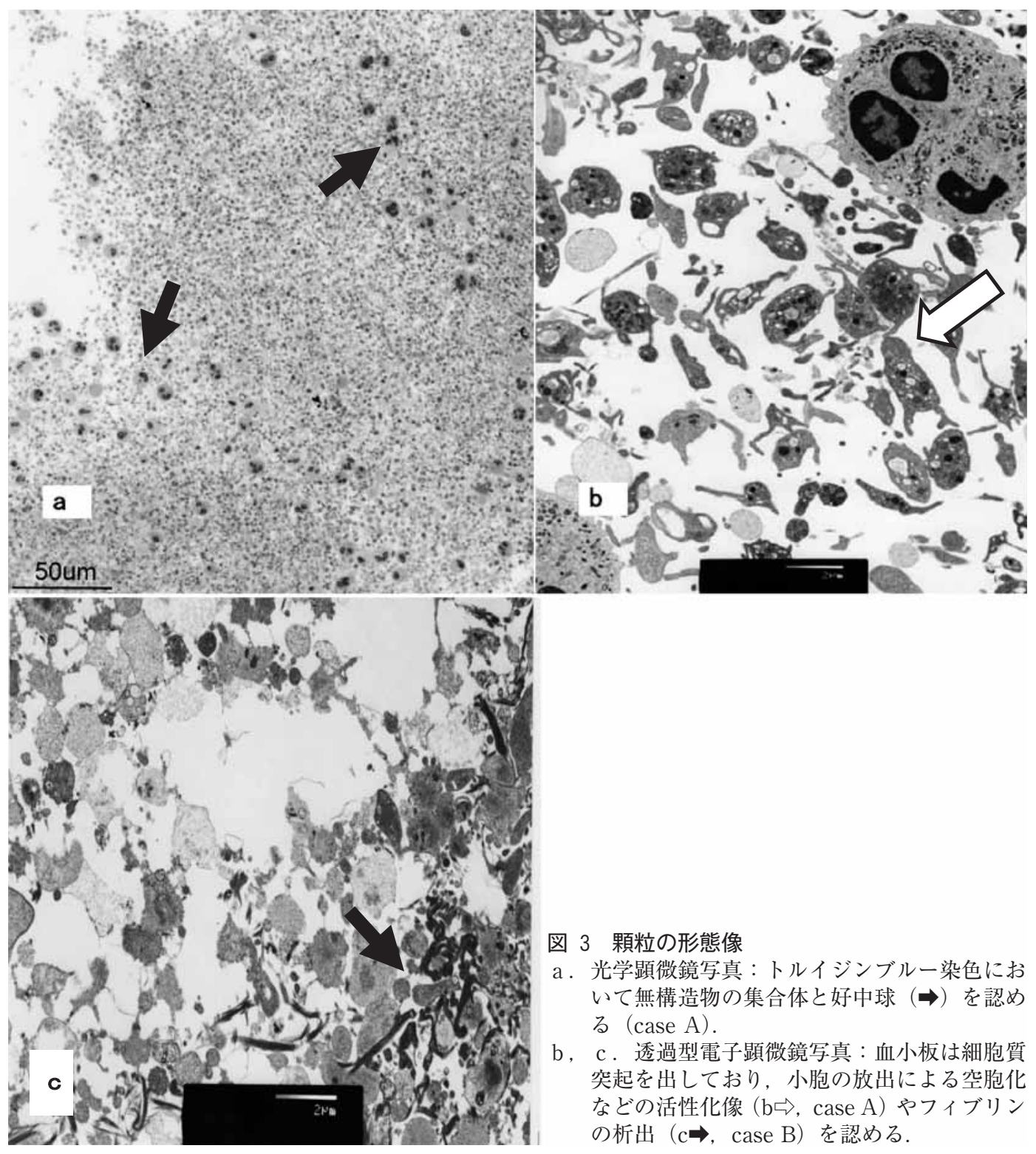

り II 型 $\mathrm{HIT}^{6)}$ は否定的であった. さらに症例は維持期 の透析患者でヘパリンを使用して数年〜十数年を経過 していること, ヘパリン使用中に血小板の進行性の減 少を示していないこと, HIT に対して唯一有効とされ る抗トロンビン薬ではなく低分子へパリンやナファモ スタットが有効であったこと，回路内加温により回避 しうることから， I 型 $\mathrm{HIT}^{6)}$ とも異なる病態であると 考えられた. ヘパリンにはアンチトロンビン III （AT III）を介した凝固因子抑制のほかに，特に高分子分画 のものに血小板凝集作用が認められる ${ }^{9)}$.この作用が 低温刺激で増強されて血栓を形成することが，低体温 下手術時の血小板減少症の成因として報告されてい $る^{10 \sim 12)}$ 。一方低分子へパリンは低温刺激による影響を 受けにくいとされ血小板凝集作用も少ない, ${ }^{9,11)}$. 今回 の症例においても低温刺激を回避する回路内加温, 低
温刺激の影響を受けにくい低分子へパリンやナファモ スタットが有効であるにもかかわらず未分画へパリン の増量には効果がなかったことから, 未分画へパリン に含まれる高分子へパリンと低温刺激が複合的に顆粒 物形成を惹起したと考えられた。

電顕像より，顆粒物の本態は血小板の活性化に伴う 血小板血栓と判定した. 血小板血栓の形成機序は血小 板の活性化に起因し，活性化因子と接触することで凝 集・粘着し血栓形成へと至る.この活性化は血小板自 身の形態を変化させ細胞質突起を出し (図 3b), 細胞 内にある $\alpha$ 顆粒, 濃染顆粒の二つの小胞に含まれる血 小板活性化因子 (プロトロンビン・ADP・TXA2 など） を放出して周囲の血小板を活性化させる ${ }^{7)}$. 特にプロ トロンビンが活性化したトロンビンでこの作用が強 く ${ }^{13)}$, さらに大量のトロンビンが生成されてフィブリ 


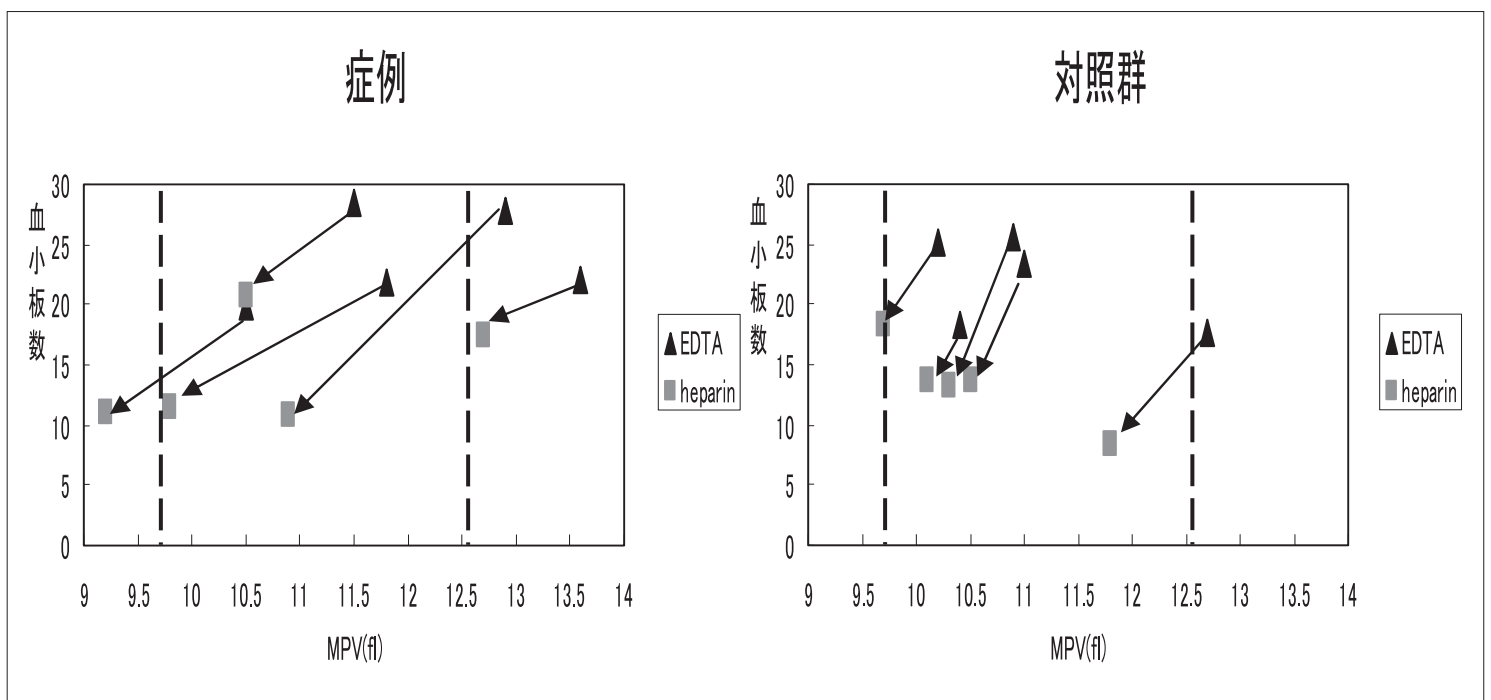

図 4 EDTA 化血とヘパリン化血での血小板数と血小板平均容積の差

症例・対照ともへパリン採血で血小板数が減少し MPV が低下した。 しかし症例ではへパリン化による MPVの 低下する割合が対照と比較して有意に大きかった（ $\mathrm{p}=0.016 ）$.

ノーゲンをフィブリンに転換し，フィブリン同士が架 橋することによって白色血栓となる，症例の血小板血 栓内には好中球のみが取り込まれ単核球はみられな かった（図 3a）ことから，血栓形成に好中球も寄与し た可能性を考える必要がある。好中球は異物と接して 遊走能や貪食能を示し活性酵素を放出し, さらにミエ ロペルオキシダーゼが血小板を活性化する ${ }^{14)}$. しかし 症例の白血球数や分画には異常がみられず，電顕上で も明らかな好中球の活性化像は認められなかった（図 3b). 一方, 血小板も物理的刺激に曝露されると von Willebrand 因子依存性に活性化し，好中球と接着する $\mathrm{P}-$ selectin を発現する ${ }^{15)}$. 異物（血液回路）に接触し て血小板が刺激され単に好中球が血栓内に巻き込まれ たものかもしれないが，症例に易出血性はなく透析時 にのみに症候を示していることから，ヘパリンと低温 刺激に加え異物に対する生体反応の関与は否定できな い.

この現象のモデル実験として，EDTA 化血とへパ リン化血を室温で保存し移送した際の血小板の数と容 積をみた（図 4)，対照と比較して症例では，血小板消 費の㐫進による血液中血小板の幼弱偏性もしくはへパ リン化による血小板の活性光進による矮小化 ${ }^{16)}$ に起因 すると考えられる MPV の逸脱を認め, さらにへパリ ン化により MPV が高度に低下（対照の $-4.5 \pm 1.3 \%$ に対して $-12.0 \pm 4.4 \%)$ した．血小板自体のへパリ ンに対する反応の強弱が症候＝顆粒物形成として現れ るか否かの差になると考えられ，EDTA 化血とへパ リン化血を 2 本同時に採取し MPV を測定することで 今回提唱した血液回路内の低温誘発性へパリン惹起血
小板血栓症の存在を推定しうると思われた．今回の検 討では，概ね $10 \%$ 以上 MPV の低下を認めた場合には 回路内に顆粒物が発症するリスクが高いと考えられる が，閾值の設定にはさらに症例数を増やして検討する 必要がある. また MPVの逸脱以外これらの症例と他 の患者との間に原疾患, 透析条件, 他覚所見, 血液検 査所見上の差異は認められず，今後も継続観察し病因 の解析を行っていきたい.

\section{結語}

低温誘発性ヘパリン惹起血小板血栓症と考えられる 症例を報告した，症例は EDTA 化血に比べヘパリン 化血による MPV の低下度が大きく，プライミング時 の回路の加温もしくは未分画へパリンから抗凝固薬の 低分子ヘパリン・ナファモスタットへの変更で改善が 認められた，低温にさらされることにより未分画へパ リンに含まれる高分子分画のヘパリンが血小板の凝集 を促進することが機序として考えられ，選択的トロン ビン阻害剂であるアルガトロバンへの変更や抗血小板 薬の使用によっても回避しうると考えられた.

謝辞：投稿にあたり，貴重なご意見を賜った，日本医 科大学解析人体病理学 清水章先生, 日本医科大学循環 器科 岡松健太郎先生, 東京警察病院リウマチ科 中島敦 先生に深謝いたします.

\section{文献}

1）木全直樹，三和奈穂子，大坪 茂，堀田 茂，岩崎富 
人, 陣内彦博, 菊地 勘, 岡野一祥, 峰島三千男, 秋 葉 隆：血液浄化療法にみられる透析回路凝固の臨床 的成因と血栓の病理学的検討. 人工臟器 $37: \mathrm{S} 132$, 2008

2) 市河三欧, 一之瀬方由利 : 慢性維持透析中クリオグロ ブリン血症を発症し回路内凝固をきたした一例. 東京 透析懇談会誌 $35: 47-50,2007$

3）大竹喜雄, 林 春幸, 横関一雄, 鹿島 孝, 入江康文, 佐久間光史, 横須賀収, 奥田邦雄 : 維持透析患者にお けるクリオグロブリン血症と C 型肝炎ウイルス感染 との関係について．透析会誌 $31:$ 119-124, 1998

4）倉田義之, 林 悟, 城崎 潔, 小西一郎, 柏木浩和, 冨山佳昭：血小板寒冷凝集素により偽性血小板減少症 を呈した 4 例. 臨床血液 47 : 781-786, 2006

5）康 秀男, 阪本親彦, 久村岳央: 寒冷凝集反応異常高 值を呈したマイコプラズマ肺炎の一例. OSAKA HEMATOLOGY REPORT $2:$ 9-12, 2004

6）宮田茂樹, 山本晴子, 河野浩之, 豊田一則, 峰松一夫： ヘパリン起因性血小板減少症. 脳神経外科ジャーナル $17:$ 909-916, 2008

7）小池 正, 服部 晃：血小板の基礎と臨床 I . 基礎形 態面. 日輸血会誌 $28: 35-39,1982$

8) Murphy S, Gardner FH : Effect of storage temperature on maintenance of platelet viability-deleterious effect of refrigerated storage. N Engl J Med 280 : 10941098, 1969
9）上野良樹，奥 和代：ヘパリンによる血小板凝集作用 機序の検討：低分子ヘパリンおよびヘパリン類似物質 との比較. 日血栓止血会誌 $17: 175-182,2006$

10）志田 寛, 森本雅己, 井之川孝一, 津金次郎, 池田 裕, 杜 英樹, 黒田孝井：単純低体温下開心術におけ る血小板の変動, 体外循環下開心術との比較. 日小外 会誌 $14: 869-873,1978$

11）重田 治, 平松祐司, 軸屋知昭, 榊原 謙：超低体温 循環停止手術における血小板機能低下. 日心血管外科 会誌 $33: 147-151,2004$

12）宮下寛子, 浅田玲子, 和中敬子, 奥宮明子：寒冷下に おける血小板凝集能に対するへパリンおよびアルガト ロバンの影響. 神戸大医学保健紀要 $20: 47-52,2004$

13）村崎かがり：抗血小板療法と動脈硬化. 循環 plus 10 : 2-6, 2010

14) Witko-Sarsat V, Gausson V, Nguyen AT, Touam M, Drueke T, Santangelo F, Descamps-Lastscha B : AOPP-induced activation of human neutrophil and monocyte oxidative metabolism. Kidney Int 64 : 82-91, 2003

15）杉本充彦, 水野智寛：高ずり速度下における血小板一 von Willebrand 因子相互作用. モレキュラーメディシ ン $41: 1501-1509,2004$

16）渡辺清明：網血小板の自動算定とその臨床的意義. 医 科器械学 $69: 35-40,1999$ 